\title{
Pengaruh Program Achievement Motivation Training (AMT) terhadap Motivasi Berprestasi dan Prestasi Mahasiswa Akademi Kebidanan
}

\author{
Lala J amilah \\ Akademi Kebidanan Bogor Husada, J. H. Soleh Iskandar No.4, \\ Kedung Badak, Tanah Sereal, Kedung Badak, Tanah Sereal, Kota Bogor, \\ Jawa Barat 16164, Tlp:(0251) 8333399 \\ Email: lala.kurniawan@gmail.com
}

\begin{abstract}
Abstrak
Hasil studi pendahuluan di Akademi Kebidanan Bogor Husada, ditemukan masalah rendahnya prestasi mahasiswa terbukti dari index prestasi lulusan tahun 2014 (IPK<2,75=37,37\%), (IPK2,75-3,50=60,6 I\%), (IPK>3,50=2,02\%), diduga karena rendahnya motivasi berprestasi mahasiswa. Beberapa penelitian menunjukkan program Achievement Motivation Training signifikan meningkatkan motivasi berprestasi. Guna mengatasi masalah tersebut perlu dilakukan penelitian apakah program Achievement Motivation Training dapat meningkatkan motivasi berprestasi mahasiswa. Rancangan penelitian, quasi experiment dengan pre-post control group design. Subjek penelitian adalah mahasiswa Akademi Kebidanan Bogor Husada. Pengambilan sampel menggunakan simple random sampling. Jumlah sampel 56 mahasiswa terdiri dari 28 mahasiswa pada grup kontrol dan 28 mahasiswa pada grup perlakuan. Analisis menggunakan uji t berpasangan, t tidak berpasangan, uji Mann-Whitney, dan uji Anakova.Hasil penelitian menunjukkan, terdapat perbedaan yang bermakna $(p<0,05)$ motivasi berprestasi antara kelompok kontrol dan kelompok perlakuan, terdapat perbedaan yang bermakna pada aspek motivasi berprestasi moderate task difficulty $(p<0,05)$, persistent $(p<0,05)$, feedback $(p<0,05)$, responsibility $(p<0,05)$ dan innovativeness $(p<0,05)$. Simpulan hasil penelitian, program achievement motivation training meningkatkan rerata motivasi berprestasi dan aspek motivasi berprestasi pada aspek moderate task difficulty, persistent, feedback, responsibility dan innovativeness.
\end{abstract}

Kata kunci : Achievement Motivation Training, motivasi, prestasi.

\begin{abstract}
The result of preliminary study at the Academy of Midwifery BogorHusada found the problem of low achievement of graduatesas shown in the Grade Point of Average in 2014 (GPA<2.75=37.37\%), (GPA 2,75-3,50=60.61\%), $(G P A>3.50=2.02 \%)$. The hypothesis was because of the low motivation for achievement of the students. Several studies showed the program of Achievement Motivation Training (AMT) significantly improved achievement motivation. To overcome the problem, it is necessary to study if the Achievement Motivation Training program can improve student's achievement motivation. The research was quasy experimental whith pre-post control group design. The subject was the students of AKBID Bogor Husada. The sampling used simple random sampling. The sample sizewas 56, consisting of 28 students in the control group and 28 students in the treatment group. The analysis utilized the paired t-test, independent $t$-test, MannWhitney test and Ancova test. The results shows that there was significant difference $(p<0.05)$ of achievement motivation between controland the treatment groups, there were significant differences in the achievement motivation aspects of the task of moderate difficulty $(p<0.05)$, persistent $(p<0.05)$, feedback $(p<0.05)$, responsibility $(p<0.05)$ and innovativeness $(p<0.05)$. The conclusion of the study is that the achievement motivation training improves mean of achievement motivation and the aspects of achievement motivation at moderate task difficulty, persistent, feedback, responsibility and innovativeness.

Keywords : Achievement Motivation Training, Achievement Motivation.
\end{abstract}




\section{Pendahuluan}

Mahasiswa bidan yang berprestasi akan mudah terbentuk pada institusi kebidanan yang memenuhi standar.Namun kondisi saat ini, Program Studi D III Kebidanan merupakan Program Studi terbanyak di Indonesia, ${ }^{1}$ menurut data Akreditasi Program Studi Kebidanan per bulan Februari 2012 yang di sampaikan oleh Direktorat Jenderal Perguruan Tinggi (Dirjen Dikti), dari 658 institusi D III Kebidanan, institusi yang belum terakreditasi 214 institusi. $^{2}$

Berdasarkan fakta tersebut mengindikasikan kondisi institusi pendidikan vokasi kebidanan belum memenuhi standar, sehingga memungkinkan untuk terlahirnya lulusan yang tidak memenuhi standar kompetensi bidan Indonesia yaitu peserta didik yang memiliki motivasi tinggi mengembangkan potensi dirinya sebagai bidan, memiliki kekuatan spiritual keagamaan, pengendalian diri, kepribadian, kecerdasan, akhlak mulia, serta keterampilan sebagai care provider, communicator, community leader, manajer dan decision maker. ${ }^{3}$

Fenomena rendahnya prestasi bidan, tergambar dalam penelitian Maulana tentang penilaian kepuasan ibu hamil terhadap mutu layanan antenatal dalam kaitannya dengan kepatuhan dan karakteristik bidan di puskesmas se kota Jambi. Hasil penelitian menunjukan rata-rata tingkat kepuasan pasien menyatakan kurang puas terhadap kinerja bidan sebanyak 46(43,8\%) dan menyatakan puas 59(56,2\%), dari variabel kepatuhan bidan dari 105 responden hanya $70(66,7 \%)$ yang dikategorikan patuh dalam memberikan asuhan antenatal. ${ }^{4}$

Rendahnya prestasi mahasiswa terjadi pula di Akademi Kebidanan (AKBID) Bogor Husada, berdasar hasil uji coba ujian kompetensi, mahasiswa yang dinyatakan tidak lulus yaitu sebesar 27,2\%, didukung juga oleh nilai index prestasi lulusan tahun 2014 (IPK $<2,75=37,37 \%$ ), (IPK2,75-3,50=60,61\%), (IPK>3,50=2,02\%).

Rendahnya prestasi mahasiswa akan sejalan dengan rendahnya kualitas lulusan terbukti dari hasil tracer study alumni AKBID Bogor Husada tahun 2011 terhadap stakeholder di beberapa puskesmas, Rumah Sakit, Bidan Praktik Mandiri (BPM) di Jawa Barat menunjukan hasil yang kurang memuaskan. Nilai aspek integritas (etika dan moral) menunjukkan nilai kurang yaitu 36,36\%,keahlian berdasarkan bidang ilmu (kompetensi utama) nilai kurang yaitu 3,04\%, kemampuan komunikasi menyatakan nilai cukup yaitu 37,33\% , kerjasama tim menyatakan nilai cukup yaitu 44\%, sedangkan kemampuan pengembangan diri menyatakan nilai cukup yaitu $42,66 \%$.
Berdasarkan beberapa faktor yang mempengaruhi prestasi tersebut, peneliti tertarik untuk meneliti faktor motivasi berprestasi, adapun alasan yang mendasari diantaranya berdasarkan hasil studi pendahuluan bagian evaluasi muncul beberapa perilaku rendahnya motivasi, dari 110 mahasiswa dalam satu minggu terdapat 5-7 mahasiswa tanpa keterangan kehadiran, 2-3 mahasiswa datang telat pada saat kuliah dimulai, dari seluruh jumlah mahasiswa setiap tahun 5$10 \%$ mahasiswa tidak lanjut kuliah sebagian besar dikarenakan jarang hadir pada saat perkuliahan. Pada proses belajar rendahnya keaktifan dan kreatifitas mahasiwa terbukti dari 110 mahasiswa hanya $10 \%$ yang aktif bertanya, ketepatan waktu mengumpulkan tugas pada proses pembelajaran dari 110 mahasiswa hanya 40\%, pada waktu menghadapi ujian, dari 110 mahasiswa, 10\% mahasiswa yang mempunyai kebisaan belajar sedini mungkin.

Rendahnya motivasi berprestasi pada mahasiswa dapat terjadi karena beberapa faktor diantaranya kurangnya situasi untuk membangkitkan motif yaitu situasi kompetensi atau bersaing dengan orang lain, hal ini dapat memperkuat usaha seseorang dalam mencapai suatu hal, masing-masing individu akan terpacu meraih hasil yang lebih baik dari prestasi yang dicapai orang lain dan utntuk mengungguli orang lain. $^{5}$

Motivasi berprestasi adalah daya penggerak untuk mencapai taraf prestasi belajar yang setinggi mungkin demi pengharapan kepada dirinya sendiri, motivasi seseorang mempunyai sifat berubah-ubah. Pentingnya motivasi berprestasi didukung oleh teori dan penelitian, menurut McClelland dan Atkinson, motivasi yang paling penting dalam psikologi pendidikan adalah motivasi berprestasi karena seseorang cenderung berjuang untuk mencapai sukses atau memilih suatu kegiatan yang berorientasi untuk tujuan sukses, mempunyai kontribusi 64\% terhadap prestasi belajar, teori tersebut selaras dengan hasil penelitian Kusurkar dkk yang meneliti hubungan motivasi terhadap prestasi akademik terhadap 383 mahasiswa kedokteran di Amsterdam, hasil dari penelitian tersebut Relative Autonomous Motivation (RAM) berkorelasi positif terhadap prestasi mahasiswa. ${ }^{6-11}$

Penelitian Sugianto, meneliti kontribusi gaya belajar dan motivasi berprestasi terhadap prestasi akademik, Berdasarkan hasil penelitian motivasi berprestasi terbukti berkontribusi besar terhadap prestasi akademik (aspek kognitif, afektif dan psikomotor). ${ }^{12}$ Dari kedua hasil penelitian tersebut, menggambarkan pentingnya meningkatkan motivasi berprestasi dalam 
meningkatkan prestasi supaya mahasiswa bidan mempunyai kualitas yang optimal dan pada akhirnya dapat memberikan pelayanan yang baik kepada masyarakat.

Berdasarkan kajian tersebut diperlukan upaya untuk meningkatkan motivasi berprestasi mahasiswa AKBID Bogor Husada supaya tercipta kualitas mahasiswa yang baik. Motivasi dapat di asah dan ditingkatkan dengan berbagai cara karena motivasi mempunyai sifat berubah-ubah, Motivasi berprestasi dapat dikembangkan dengan pelatihan motivasi atau Achievement Motivation Training (AMT) sehingga mahasiswa AKBID Bogor Husada lebih baik lagi dalam menghadapi proses belajarnya.

Achievement Motivation Training (AMT) atau pelatihan motivasi berprestasi merupakan program pelatihan yang didasarkan pada penelitian oleh David McClelland dan rekanrekannya di Harvard University yang di rancang dengan baik, berbasis bukti penelitian, memiliki basis teoritis yang kuat, program ini berulang kali telah terbukti efektif meningkatkan motivasi berprestasi dan kinerja. ${ }^{13}$

Pentingnya pemberian AMT tersebut, sesuai dengan theory of human motives yang disampaikan oleh David McClelland, dalam teori tersebut manusia mempunyai kebutuhan untuk berprestasi (the need of achievement). ${ }^{14-15}$ Teori tersebut diperkuat dengan hasil penelitian Elias dan Rahman, setelah diberikan AMT terdapat peningkatan yang signifikan antara kelompok pengembangan diri dan kelompok kontrol dalam aspek afektif motivasi berprestasi $(p<0,5)$ dan kognitif motivasi berprestasi $(\mathrm{p}<0,5){ }^{16}$

Berdasarkan kajian tentang fenomena rendahnya kualitas mahasiswa bidan menurut teori dan fakta yang relevan, maka dapat ditetapkan masalah penelitian (problem of research) dalam penelitian ini adalah rendahnya motivasi berprestasi mahasiswa AKBID Bogor Husada. Hasil kajian teori dan fakta tersebut menggambarkan perlunya solusi untuk memecahkan masalah yang sedang dihadapi melalui program pelatihan motivasi untuk berprestasi atau Achievement Motivation Training.

\section{Metode}

Rancangan penelitian yang digunakan dalam penelitian ini adalah eksperimen semu (Quasi Experiment), dengan desain pre testpost test control group design. Rancangan ini digunakan untuk menilai sebab akibat atau pengaruh suatu intervensi atau perlakuan.

Variabel dalam penelitian ini terdiri dari 2 variabel yang akan diukur yaitu; (1) variabel independen/variabel bebas, (2) Variabel dependen/variabel terikat. Untuk memudahkan mendapatkan hasil pengukurannya dalam statistik, variabel tersebut telah dikategorikan sesuai dengan jenis data dan skala pengukurannya. Variabel independen adalah program Achievement Motivation Training sedangkan Variabel dependen adalah Motivasi berprestasi.

Populasi target dalam penelitian ini adalah seluruh mahasiswa Akademi Kebidanan Bogor Husada semester IV, sedangkan populasi terjangkau adalah mahasiswa AKBID Bogor Husada tingkat II tahun 2011/2012 yang memenuhi kriteria inklusi dan eksklusi serta bersedia ikut dalam penelitian ini.

Sampel dalam penelitian ini adalah seluruh mahasiswa AKBID Bogor Husada tingkat II yang memenuhi kriteria inklusi dan eksklusi dan memenuhi besar sampel minimal, adapun teknik sampel yang digunakan adalah simple random sampling dengan alasan populasi dianggap homogen. ${ }^{17}$ Sampel dalam penelitian ini yaitu 28 mahasiswa untuk kelompok intervensi dan 28 mahasiswa untuk kelompok kontrol.

Alat pengumpulan data untuk mengukur motivasi dalam penelitian ini adalah dengan menggunakan kuesioner tertutup, sedangkan jawaban yang diberikan bersifat kuesioner langsung dimana responden menjawab atau memberikan respon tentang keadaan dirinya. ${ }^{18}$

Kuesioner disusun dengan memperhatikan beberapa prinsip yaitu: isi dan tujuan pertanyaan disesuikan dengan informasi yang ingin dicari, dalam hal ini informasi yang di cari motivasi berprestasi apapun pertanyataan disesuaikan dengan aspek motivasi berprestasi dari McClelland, bahasa yang digunakan disesuaikan dengan kondisi responden dalam hal ini mahasiswa kebidanan, pernyataan tidak menggiring ke jawaban yang baik saja atau jelek, maka dari itu kuesioner dalam penelitian ini tidak semua pernyataan positif tetapi terdapat beberapa pernyataan negatif, penampilan fisik kuesioner penting diperhatikan karena mempengaruhi respon atau keseriusan responden dalam hal ini quesioner menggunakan kertas putih, tidak meggunakan kertas buram. ${ }^{18}$

Penelitian terhadap responden dimulai dari pengujian kelayakan kuesioner penelitian diperoleh. Uji validitas yang digunakan untuk menguji ketepatan ítem pertanyaan dalam mengukur informasi yang diinginkan oleh peneliti dalam penelitian ini dilakukan dengan menggunakan koefisien korelasi pearson. Uji reliabilitas yang digunakan untuk menguji konsistensi kuesioner dalam mengukur informasi yang diinginkan oleh peneliti dalam penelitian ini 
dilakukan dengan menggunakan koefisien reliabilitas alpha cronbach.

Pengujian validitas pertanyaan kuesioner variabel motivasi berprestasi dengan 60 item pertanyaan menghasilkan nilai koefisien validitas yang bervariasi pada tiap item pertanyaan. Item pertanyaan tergolong valid jika mempunyai nilai koefisien validitas yang lebih besar dari nilai batas dengan kriteria valid yaitu 0.3. Dengan demikian dapat dikatakan bahwa terdapat 50 item pertanyaan yang valid dan 10 item pertanyaan yang tidak valid. Item pertanyaan yang tidak valid adalah item pertanyaan nomor $1,15,16,27,36$, 44, 45, 46, 56, dan 57. Pengujian ulang dilakukan dengan tidak mengikut sertakan item-item pertanyaan yang tidak valid tersebut.

Pengujian ulang validitas pertanyaan kuesioner variabel motivasi berprestasi dilakukan dengan mengeluarkan satu per satu item pertanyaan yang tidak valid dari analisis. Seluruh item pertanyaan yang diuji telah valid karena mempunyai nilai koefisien validitas yang lebih besar dari nilai batas atau kriteria validnya, yaitu 0.3.Nilai koefisien validitas ini menunjukkan bahwa item pertanyaan pada kuesioner ini telah mampu mengukur informasi yang diinginkan oleh peneliti. Nilai koefisien reliabilitas yang dihasilkan dari 50 item pertanyaan tersebut yang mencapai 0.961 juga telah berada di atas kriteria yang ditetapkan yaitu 0.7. Nilai koefisien reliabilitasnya (0.961) menunjukkan kuesioner tersebut mempunyai keandalan yang baik dalam mengukur variabel motivasi berprestasi. Dengan demikian, kuesioner variabel motivasi berprestasi sudahlayak dipergunakan untuk analisis.

Identifikasi penelitian dilakukan untuk mendapat subjek yang sesuai dengan menggunakan propability sampling dengan cara simple random sampling. Adapun alasannya yaitu supaya responden mendapatkan kesempatan yang sama untuk diikutsertakan dalam penelitian, untuk menyamakan kelompok kontrol dan perlakuan sehingga validitas interna tidak terancam, sistem randomisasi dengan menggunakan sistem undian yaitu kelas 2 A masing-masing diberikan nomor sesuai nomor absen yaitu 1-54 dan kelas 2 B nomor 55-108, kemudian peneliti mengambil 28 kertas undian untuk kelompok kontrol dan 28 kertas undian untuk kelompok intervensi.

Teknik pengumpulan data pada penelitian ini dengan menggunakan kuesioner atau angket, alasannya karena dengan menggunakan angket sebagai teknik pengumpulan data; tidak memerlukan hadirnya peneliti secara langsung, waktu pelaksanaan relatif lebih cepat dan pemilihan waktu bebas, berhubung data yang ingin diambil mengenai motivasi, pernyataan atau pertanyaan dapat dijawab sesuai kondisi karena angket dapat mengukur pelaporan diri. ${ }^{18,20}$

Perlakuan pada kelompok intervensi, AMT diberikan satu kali pertemuan diberikan dalam 1 hari dengan durasi waktu 6 jam setiap hari, dalam hal ini peneliti mengacu kepada penelitian McClelland yang telah diadaptasi oleh Ashton. Sebelum diberikan AMT respoden diambil pretest.

Waktu pengumpulan data Pre test dilakukan secara serentak antar kelompok kontrol dan kelompok intervensi. Adapun tempat pengambilan data dilakukan di kelas usai jam pelajaran selesai.

Waktu pengambilan data post test untuk kelompok kontrol dan intervensi dilakukan secara setentak juga di dalam kelas dengan jarak 2 bulan setelah kelompok intervensi diberikan AMT. Penentuan waktu 2 bulan berdasar penelitian Elias, Lovez, Chair dana Havenar. Berdasarkan beberapa penelitian tersebut setelah diberikan training motivasi dan diamati setiap minggu maka terjadi peningkatan, adapun peningkatan tersebut dapat terlihat pada 6 minggu setelah dilakukan perlakuan, pada bulam ke 3 mengalami kenaikan motivasi yang pesat dan puncak peningkatan motivasi terjadi pada bulan ke 6 kemudian pada penilaian bulan ke 9 terjadi penurunan dari nilai maksimal dan pada bulan ke 12 semakin penurunan tetapi nilai tersebut masih diatas nilai awal (baseline). Perubahan motivasi tersebut didukung oleh berbagai teori, motivasi mempuyai sifat berubah-ubah dan dipengaruhi oleh beberapa faktor intrinsik maupun ekstrinsik. ${ }^{16,21-23}$ Adapun alasan dilakukan pengambilan pos-test setelah 2 bulan diberikan perlakuan karena pada waktu itu sudah terdapat peningkatan motivasi berprestasi. Untuk menciptakan sifat justice dalam aspek etik penelitian AMT diberikan kepada kelompok kontrol 1 bulan setelah pengambilan post test.

Penelitian dilakukan di tempat bekerja responden mahasiswa Akademi Kebidanan (AKBID) Bogor Husada sedangkan waktu penelitian bulan Juni - Agustus 2014.

\section{Hasil}

Hasil penelitian dan analisa yang berhubungan dengan judul "pengaruh program Achievement Motivation Training (AMT) terhadap motivasi berprestasi mahasiswa Akademi Kebidanan Bogor Husada”. Penelitian dilaksanakan terhadap 56 orang responden yang terdiridari 28 orang responden kelompok intervensi AMT dan 28 orang responden kelompok kontrol. Analisis yang akan disajikan adalah analisis deskriptif dan analisis analitik. Analisis deskriptif dilakukan dengan pengolahan data untuk memperoleh gambaran data berupa 
ukuran pemusatan data. Analisis analitik dilakukan dengan menggunakan uji statistik $t$ jika data berdistribusi normal atau Mann-Whitney jika data tidak berdistribusi normal yang digunakan untuk menguji motivasi berprestasi mahasiswa berdasarkan pengaruh program AMT yang telah diberikan.

Analisis peningkatan motivasi berprestasi pada kelompok intervensi AMT dan kelompok control tanpa AMT dilakukan dengan menggunakan uji t. Hasil analisisnya adalah sebagaiberikut :

Tabel 1. Perbandingan Motivasi Berprestasi Mahasiswa Sebelum Dan Sesudah AMT

\begin{tabular}{|c|c|c|c|}
\hline Variabel & $\begin{array}{c}\text { Kontrol } \\
(n=28)\end{array}$ & $\begin{array}{c}\text { Intervensi } \\
(n=28)\end{array}$ & $\begin{array}{c}\text { Nilai } \\
\mathbf{P}\end{array}$ \\
\hline \multicolumn{4}{|l|}{ Motivasi } \\
\hline \multicolumn{4}{|l|}{ Berprestasi } \\
\hline \multicolumn{4}{|l|}{ Pre-Test } \\
\hline Rendah & 0 & 0 & \\
\hline Sedang & 25 & 24 & \\
\hline Tinggi & 3 & 4 & \\
\hline \multicolumn{4}{|l|}{ Post Test } \\
\hline Rendah & 1 & 0 & \\
\hline Sedang & 22 & 18 & \\
\hline Tinggi & 5 & 10 & \\
\hline \multicolumn{4}{|l|}{ Motivasi } \\
\hline \multirow{2}{*}{\multicolumn{4}{|c|}{$\begin{array}{l}\text { Berprestasi } \\
\text { Pre test }\end{array}$}} \\
\hline & & & \\
\hline $\begin{array}{l}\text { Mean } \\
\text { (SD) }\end{array}$ & $140,11(18,98)$ & $138,75(9,48)$ & \\
\hline Rentang & 103-191 & $121-159$ & $0,369 *$ \\
\hline \%rata-rata & 70,06 & 69,38 & \\
\hline Kategori & Sedang & Sedang & \\
\hline \multicolumn{4}{|l|}{ Post test } \\
\hline $\begin{array}{l}\text { Mean } \\
\text { (SD) }\end{array}$ & $149,82(14,63)$ & $135,43(15,21)$ & \\
\hline Rentang & $123-180$ & $99-158$ & $0,000 *$ \\
\hline \%rata-rata & 74,91 & 67,72 & \\
\hline Kategori & Sedang & Sedang & \\
\hline Nilai P & \multicolumn{2}{|c|}{$0,000 * *$} & \\
\hline
\end{tabular}

Tabel 1 memuat hasil analisis deskriptif kategori responden, $t$ independen dan hasil uji anakova pada motivasi berprestasi mahasiswa. Hasil uji $t$-independen menunjukkan bahwa motivasi berprestasi tidak mengalami perbedaan yang bermakna $(p>0,05)$ pada saat sebelum diberikan perlakuan. Sementara itu, motivasi berprestasi mengalami perbedaan yang bermakna $(p<0,05)$ pada saat setelah diberikan perlakuan.

Hasil uji anakova pada tabel 1 menunjukkan bahwa motivasi berprestasi menunjukkan perbedaan yang bermakna $(p<0,05)$. Motivasi berprestasi dipengaruhi secara signifikan oleh perbedaan perlakuan yang diberikan dengan melakukan control terhadap responden sebelum diberikan perlakuan.

Tabel 2 memuat hasil analisis deskriptif data dan hasil uji $t$-berpasangan pada motivasi berprestasi mahasiswa. Hasil uji $t$-berpasangan menunjukkan bahwa motivasi berprestasi mengalami peningkatan yang bermakna $(p<0,05)$ pada kelompok intervensi AMT. Sementara itu, motivasi berprestasi tidak mengalami penurunan yang bermakna $(\mathrm{p}>0,05)$ pada kelompok kontrol tanpa AMT.

Hasil uji $t$-independen pada tabel 2 menunjukkan bahwa motivasi berprestasi menunjukkan perbedaan yang tidak bermakna $(\mathrm{p}>0,05)$ pada kondisi sebelum perlakuan diberikan pada kedua kelompok. Artinya, kedua kelompok homogen dengan motivasi berprestasi awal yang relatif sama. Selanjutnya, setelah diberikan perlakuan berbeda pada kelompok intervensi AMT dan kelompok kontrol tanpa AMT, didapatkan hasil perbedaan yang bermakna $(p<0.05)$ pada motivasi berprestasi. Kesimpulan ini juga didukung berdasarkan hasil selisih motivasi berprestasi kedua kelompok yang menunjukkan hasil perbedaan yang bermakna $(p<0.05)$.

Tabel 3 memuat hasil analisis deskriptif data dan hasil uji $t$-independen pada aspek motivasi berprestasi mahasiswa. Hasil uji $t$ independen menunjukkan bahwa pada kondisi sebelum perlakuan diberikan pada kedua kelompok, aspek Moderate Task Difficulty, Persistence, Feedback, Responsibility, dan Innovativeness menunjukkan perbedaan yang tidak bermakna $(p>0.05)$. Artinya, kedua kelompok relatif homogen pada setiap aspek motivasi berprestasi dalam kondisi sebelum diberikan perlakuan. Selanjutnya, setelah diberikan perlakuan berbeda pada kelompok intervensi AMT dan kelompok kontrol tanpa AMT, didapatkan hasil perbedaan yang bermakna $(p<0.05)$ pada aspek Modern Task Difficulty, Persistence, Feedback, Responsibility, dan Innovativeness. Perbedaan selisih skor aspek Modern Task Difficulty, Persistence, Feedback, Responsibility, dan Innovativeness juga memperlihatkan perbedaan yang bermakna $(p<0.05)$.

\section{Pengujian Hipotesis Penelitian}

Berdasarkan hasil analisis statistik yang diperoleh selanjutnya dilakukan pengujian hipotesis. 
Tabel 2. Peningkatan Motivasi Berprestasi MahasiswaPada Kelompok AMT dan Kelompok Kontrol Tanpa AMT

\begin{tabular}{|c|c|c|c|c|c|}
\hline \multirow{2}{*}{ Variabel } & \multicolumn{2}{|c|}{ Kontrol $(n=28)$} & \multicolumn{2}{|c|}{ Intervensi $(\mathrm{n}=\mathbf{2 8})$} & \multirow[b]{2}{*}{ Nilai $\mathbf{P}$} \\
\hline & Pre & Post & Pre & Post & \\
\hline \multicolumn{6}{|l|}{ Motivasi Berprestasi } \\
\hline Mean (SD) & $138,75(9,48)$ & $135,43(15,21)$ & $140,11(18,98)$ & $149,82(14,63)$ & \\
\hline Median & 139,5 & 139 & 138,5 & 145,5 & \\
\hline Rentang & $121-159$ & $99-158$ & $103-191$ & $123-180$ & \\
\hline \%rata-rata & 69,38 & 67,72 & 70,06 & 74,91 & \\
\hline Kategori & Sedang & Sedang & Sedang & Sedang & \\
\hline t hitung & \multicolumn{2}{|c|}{$-1,545$} & \multicolumn{2}{|c|}{2,892} & \\
\hline Nilai p & \multicolumn{2}{|c|}{0,067} & \multicolumn{2}{|c|}{0,004} & \\
\hline \multicolumn{6}{|c|}{ Selisih Motivasi Berprestasi } \\
\hline Mean (SD) & \multicolumn{2}{|c|}{$3,32(11,37)$} & \multicolumn{2}{|c|}{$9,71(17,78)$} & \\
\hline Median & \multicolumn{2}{|c|}{1,00} & \multicolumn{2}{|c|}{8,5} & 0,001 \\
\hline Rentang & \multicolumn{2}{|c|}{$-37-13$} & \multicolumn{2}{|c|}{$-23-49$} & \\
\hline \% Peningkatan Rerata & \multicolumn{2}{|c|}{$-2,39$} & \multicolumn{2}{|c|}{6,93} & \\
\hline
\end{tabular}

\section{PengujianHipotesisPenelitian Hipotesis Pertama \\ Program Achievement Motivation}

Training berpengaruh positif terhadap motivasi berprestasi mahasiswa.

\section{Hal yang Menunjang}

Berdasarkan tabel 4.1, pemberian Achievement Motivation Training memberikan peningkatan signifikan pada motivasi berprestasi mahasiswa Akademi Kebidanan Bogor Husada sesudah program dilakukan dengan nilai $p<0,05$. Selain itu, AMT juga lebih baik dalam mempengaruhi peningkatan motivasi berprestasi mahasiswa AKBID Bogor Husada dibandingkan program tanpa AMT seperti kesimpulan yang dikemukakan berdasarkan tabel 4.1.

\section{Hal yang tidak Menunjang}

Tidak ada hal yang tidak menunjang

\section{Kesimpulan}

Hipotesis teruji dan diterima.

\section{Pembahasan}

Motivasi berprestasi mempunyai beberapa aspek yang dapat dijadikan ukuran seseorang memiliki motivasi berprestasi yang baik atau buruk. Aspek tersebut adalah; Moderate task difficulty/memilih tugas dengan tingkat kesulitan sedang, Persistence/ ketahanan atau ketekunan, Feedback/ Umpan balik, Responsibility/ bertanggung jawab, Innovativeness/ memiliki inovasi. ${ }^{24-26}$

Penelitian ini dilakukan di Akademi Kebidanan (AKBID) Bogor Husada, berdasarkan hasil evaluasi dari bagian evaluasi pendidikan
AKBID Bogor Husada, dari 110 mahasiswa dalam satu minggu terdapat 5-7 mahasiswa tanpa keterangan kehadiran, 2-3 mahasiswa datang telat pada saat kuliah dimulai, dari seluruh jumlah mahasiswa setiap tahun 5-10\% mahasiswa tidak lanjut kuliah sebagian besar dikarenakan jarang hadir pada saat perkuliahan. Pada proses belajar rendahnya keaktifan dan kreatifitas mahasiwa terbukti dari 110 mahasiswa hanya 10\% yang aktif bertanya, ketepatan waktu mengumpulkan tugas pada proses pembelajaran dari 110 mahasiswa hanya $40 \%$.

Kondisi demikian selaras dengan hasil analisis data yang tertuang dalam tabel 4 Diketahui Hasil uji t-independen menunjukkan bahwa motivasi berprestasi pada kelompok intervensi dan kontrol pada tahap sebelum perlakuan menunjukkan perbedaan yang tidak bermakna ( $p>0.05$ ), artinya kedua kelompok homogen, aspek motivasi berprestasi antara kelompok kontrol maupun kelompok intervensi relatif sama tetapi setelah dikategorin dengan 3 kategori motivasi berprestasi mahasiswa sebelum perlakuan terdapat pada kategori sedang. Berdasarkan data tersebut motivasi berprestasi mahasiswa belum baik.

Berdasarkan teori, motivasi berprestasi mendorong seseorang untuk mencapai keberhasilan dalam bersaing dengan suatu ukuran keunggulan, didasarkan atas dua hal, yaitu tendensi untuk meraih sukses dan tendensi untuk menghindari kegagalan. Individu yang memiliki motivasi berprestasi yang tinggi berarti ia memiliki motivasi untuk meraih sukses yang lebih kuat daripada motivasi untuk mengindari kegagalan, begitu pula sebaliknya. ${ }^{8}$ 


\begin{tabular}{|c|c|c|c|c|c|c|c|}
\hline Variabel & $\begin{array}{c}\text { Kontrol } \\
(\mathrm{n}=\mathbf{2 8})\end{array}$ & $\begin{array}{c}\text { Intervensi } \\
(\mathrm{n}=\mathbf{2 8})\end{array}$ & Nilai P & & $\begin{array}{c}\text { Kontrol } \\
(n=28)\end{array}$ & $\begin{array}{c}\text { Intervensi } \\
(\mathrm{n}=\mathbf{2 8})\end{array}$ & Nilai P \\
\hline \multicolumn{8}{|l|}{ Moderate to Difficulty } \\
\hline Pre test & & & & Post test & & & \multirow{8}{*}{$0,015^{* *}$} \\
\hline Mean (SD) & $16,93(1,49)$ & $17,21(1,31)$ & \multirow{5}{*}{$0,450 * *$} & Mean (SD) & $16,57(1,43)$ & $17,71(1,46)$ & \\
\hline Median & 17,00 & 17,00 & & Median & 17,00 & 17,00 & \\
\hline Rentang & $14-20$ & $14-24$ & & Rentang & $12-20$ & $15-21$ & \\
\hline \%rata-rata & 70,54 & 71,71 & & \%rata-rata & 69,04 & 73,79 & \\
\hline Kategori & Sedang & Sedang & & Kategori & Sedang & Sedang & \\
\hline Selisih rerata & $-0,36$ & 0,5 & \multirow{2}{*}{$0,040 * *$} & & & & \\
\hline \%Peningkatan Rerata & $-2,31$ & 2,91 & & & & & \\
\hline \multicolumn{8}{|l|}{ Persistence } \\
\hline Pre test & & & & Post test & & & \multirow{8}{*}{$0,002 * *$} \\
\hline Mean (SD) & $27,71(2,72)$ & $27,86(4,39)$ & \multirow{5}{*}{$0,251 * *$} & Mean (SD) & $26,43(4,00)$ & $29,86(3,37)$ & \\
\hline Median & 36,50 & 27,00 & & Median & 26,00 & 29,00 & \\
\hline Rentang & $19-23$ & $20-38$ & & Rentang & $16-32$ & $25-37$ & \\
\hline \%rata-rata & 69,28 & 69,65 & & \%rata-rata & 66,08 & 74,65 & \\
\hline Kategori & Sedang & Sedang & & Kategori & Sedang & Sedang & \\
\hline Selisih rerata & $-1,28$ & 2 & \multirow{2}{*}{$0,001^{* *}$} & & & & \\
\hline \%Peningkatan Rerata & $-4,62$ & 7,18 & & & & & \\
\hline \multicolumn{8}{|l|}{ Feedback } \\
\hline Pre test & & & & Post test & & & \multirow{8}{*}{$0,003 *$} \\
\hline Mean (SD) & $36,50(2,73)$ & $36,46(5,55)$ & \multirow{5}{*}{$0,371^{* *}$} & Mean (SD) & $36,04(4,55)$ & $39,43(4,37)$ & \\
\hline Median & 36,50 & 36,00 & & Median & 37,00 & 39,00 & \\
\hline Rentang & $31-43$ & $23-50$ & & Rentang & $24-42$ & $30-49$ & \\
\hline \%rata-rata & 70,19 & 70,12 & & $\%$ rata-rata & 69,31 & 75,83 & \\
\hline Kategori & Sedang & Sedang & & Kategori & Sedang & Tinggi & \\
\hline Selisih rerata & $-0,46$ & 2,97 & \multirow{2}{*}{$0,004 * *$} & & & & \\
\hline \%Peningkatan Rerata & $-1,26$ & 8,15 & & & & & \\
\hline \multicolumn{8}{|l|}{ Responsibility } \\
\hline Pre test & & & & Post test & & & \multirow{8}{*}{$0,004 * *$} \\
\hline Mean (SD) & $19,46(1,75)$ & $19,86(2,77)$ & \multirow{5}{*}{$0,272 * *$} & Mean (SD) & $19,21(2,17)$ & $21,04(2,33)$ & \\
\hline Median & 19,00 & 19,00 & & Median & 19,00 & 20,00 & \\
\hline Rentang & $17-24$ & $14-28$ & & Rentang & $14-24$ & $18-26$ & \\
\hline \%rata-rata & 69,50 & 70,93 & & \%rata-rata & 68,61 & 75,14 & \\
\hline Kategori & Sedang & Sedang & & Kategori & Sedang & Tinggi & \\
\hline Selisih rerata & $-0,25$ & 1,18 & \multirow{2}{*}{$0,019 * *$} & & & & \\
\hline \%Peningkatan Rerata & $-1,28$ & 5,94 & & & & & \\
\hline \multicolumn{8}{|l|}{ Innovativeness } \\
\hline Pre test & & & & Post test & & & \multirow{8}{*}{$0,001 * *$} \\
\hline Mean (SD) & $38,43(3,36)$ & $38,93(6,04)$ & \multirow{5}{*}{$0,352^{*}$} & Mean (SD) & $37,21(4,50)$ & $42,04(4,55)$ & \\
\hline Median & 39,00 & 38,00 & & Median & 37,00 & 42,00 & \\
\hline Rentang & $31-44$ & $28-53$ & & Rentang & $28-46$ & $35-52$ & \\
\hline \%rata-rata & 68,63 & 69,52 & & \%rata-rata & 66,45 & 75,07 & \\
\hline Kategori & Sedang & Sedang & & Kategori & Sedang & Tinggi & \\
\hline Selisih rerata & $-1,22$ & 3,11 & \multirow{2}{*}{$0,002^{*}$} & & & & \\
\hline \%Peningkatan Rerata & $-3,17$ & 7,99 & & & & & \\
\hline
\end{tabular}

Mengacu teori tersebut, motivasi berprestasi mahasiswa perlu mendapatkan perhatian lebih sesuai dengan pendapat ahli, motivasi yang paling penting dalam psikologi pendidikan adalah motivasi berprestasi karena seseorang cenderung berjuang untuk mencapai sukses atau memilih suatu kegiatan yang berorientasi untuk tujuan sukses. ${ }^{7-8}$

Aspek motivasi berprestasi diharapkan dapat melekat pada mahasiswa sebagaimana yang tercantum dalam pedoman akademik sistem pendidikan bidan Indonesia, seorang mahasiswa bidan harus memiliki jiwa tanggung jawab, mampu berfikir kritis dalam melakukan tugasnya. Harapan tersebut di aplikasikan dalam berbagai perubahan pendekatan pembelajaran dengan tujuan menigkatkan motivasi mahasiswa. ${ }^{27}$

Selain kebijakan tersebut, pentingnya motivasi berprestasi untuk kesuksesan mahasiswa dibuktikan dalam beberapa penelitian, penelitian yang menghubungkan motivasi berprestasi dengan prestasi akademik dilakukan terhadap 252 
mahasiswa di universitas Tehran, analisis yang digunakan Pearson Correlation coefficien terbukti berpengaruh secara signifikan. ${ }^{28}$

Hal serupa terdapat dalam penelitian Faturachman mengenai pengaruh motivasi berprestasi terhadap kesiapan belajar, pelaksanaan prakerin dan pencapaian kompetensi mata pelajaran produktif teknik kendaraan ringan kelas XI, hasil pengolahan korelasi dan koefisien determinasi diperoleh: motivasi berprestasi terhadap kesiapan belajar berkorelasi tinggi sebesar 0,875; terhadap pelaksanaan prakerin sebesar 0,678. Sedangkan kesiapan belajar terhadap pencapaian kompetensi mata pelajaran produktif berkorelasi sebesar 0,392; pelaksanaan prakerin berkorelasi sebesar 0,381 terhadap pencapaian kompetensi mata pelajaran produktif; kesiapan belajar dan pelaksanaan prakerin secara bersama-sama berkorelasi sebesar 0,418. Kesimpulan dari penelitian ini adalah adanya pengaruh yang signifikan motivasi berprestasi dengan kesiapan belajar dan pelaksanaan prakerin. ${ }^{29}$

Berdasar fenomena dan hasil analisa pada penelitian ini diperlukan upaya untuk meningkatkan motivasi berprestasi pada mahasiswa AKBID Bogor Husada. Upaya yang diberikan kepada mahasiswa adalah dengan diberikannya pelatihan motivasi berprestasi dengan harapan motivasi berprestasi mahasiswa menjadi meningkat.

Achievement Motivation Training (AMT) merupakan program pelatihan berbasis bukti penelitian, memiliki basis teoritis yang kuat yang bertujuan untuk meningkatkan motivasi berprestasi, memahami tujuan, dapat mempraktikan dan menemukan berbagai model tindakan prestatif, merencanakan dan membantu menyenangi umpan balik terhadap kemajuan usaha untuk mencapai tujuan, program pelatihan yang didasarkan pada penelitian oleh David McClelland dan rekan-rekannya di Harvard University. ${ }^{13,30}$

Berbagai penelitian mengenai efektifitas AMT sudah banyak dilakukan, semua penelitian tersebut memberikan hasil yang bermakna terhadap variabel yang diteliti, penelitian di India oleh David McClelland membuktikan bahwa AMT berhasil meningkatkan perilaku bisnis para mengusaha menengah, begitu juga hasil dengan penelitian di Amerika Serikat dan California oleh McClelland, AMT terbukti signifikan meningkatkan $\mathrm{n}$ achievement para siswa.83 Hasil penelitian Lovez menunjukkan AMT dapat ,meningkatkan prestasi terkait perilaku, locus of control, efikasi diri, orientasi tujuan intrinsik dan ekstrinsik. Analisis yang digunakan adalah analisis faktor multivariat campuran kovarians (MANCOVA) dengan tindakan berulang, Efekutama kelompok pada locus of control menunjukkan signifikansi, $\Lambda=0,907, \quad F(4,95)$ $=2,445, \mathrm{p}<.05, \eta 2=0,093$. Analisis univariat pada pre dan post menunjukkan perubahan yang signifikan, $F(1,98)=4,512, p<0,036$ dan $\eta$ parsial $2=0,044$. $^{13,21}$

Penelitian ini dilakukan atas dasar penelitian McClelland, dimana achievement motivation training diberikan kepada sekelompok mahasiswa kebidanan yang sedang melakukan kegiatan perkuliahan baik di kelas maupun di lahan praktik dengan maksud untuk meningkatkan motivasi berprestasi mahasiswa. Pelaksanaan perlakukan achievement motivation training ini dilakukan 1 hari dengan durasi waktu 6 jam berdasar penelitian Ashton yang mengadopsi dari penelitian McClelland. ${ }^{16}$

Berdasarkan tabel 4.1 analisis data dengan menggunakan uji $\mathrm{t}$ berpasangan, hasil menunjukkan adanya peningkatan yang bermakna motivasi berprestasi pada kelompok intervensi ( $\mathrm{p}<$ $0,05)$ setelah diberikan perlakuan. Kemudian peneliti melakukan analisis uji perbedaan efek program AMT terhadap peningkatan Motivasi berprestasi dengan menggunakan uji $t$ independen, hasil menunjukkan perbedaan yang bermakna $(\mathrm{p}<0,05)$, kesimpulan ini juga didukung berdasarkan hasil selisih motivasi berprestasi kedua kelompok yang menunjukkan hasil perbedaan yang bermakna $(\mathrm{p}<0.05)$.

Hasil penelitian ini sejalan dengan hasil penelitian Elias yang meneliti efek Achievement motivation training terhadap motivasi berprestasi dari segi afektif dan kognitif, dilakukan pada 188 mahasiswa pertanian di Malaysia dengan menggunakan desain penelitian quasy experiment pre-post group control design, penelitiannya mengukur motivasi berprestasi dengan TAT (Thematic Apperception Test), MOT (Motivation Scale), RIES (Rotter Internal-External Scale, an attribution scale adapted from the causal dimension scale. hasil penelitian menunjukkan AMT memberikan hasil yang signifikan terhadap peningkatan motivasi berprestasi afektif $(\mathrm{F}(2,164)$ $=44.4, \mathrm{k}<.05)$ dan signifikan terhadap peningkatan motivasi berprestasi kognitif $(\mathrm{F}(2,155)=16.56, \mathrm{k}<.05) .{ }^{16}$

Hasil analisis pada tiap aspek motivasi berprestasi tidak jauh beda dengan hasil motivasi berprestasi secara keseluruhan. Pada tabel 4.5 aspek moderate task difficulty, persistence, feedback, responsibility dan innovatiness menunjukkan hasil perbedaan yang bermakna $(p<0,05)$. Sedangkan dari hasil peningkatan rerata setiap aspek motivasi berprestasi menunjukkan 
hasil, AMT dapat meningkatkan aspek moderate task difficulty 2,91\%, persistence 7,18\%, feedback $8,15 \%$, responsibility $5,94 \%$ dan innovatiness $7,99 \%$.

Achievement motivation training memiliki 4 elemen program perubahan yang dapat membantu meningkatkan motivasi berprestasi mahasiswa, elemen tersebut yaitu Achievement Syndrom/ Conceptualization of The Motive merupakan pengenalan konsep mengenai apakah yang dimaksud dengan motif dan motivasi berprestasi. Setelah mengenali dan memahami apakah yang dimaksud dengan motivasi berprestasi beserta ciri-ciri orang yang memiliki motivasi berprestasi, perilaku tersebut mencakup 5 aspek motivasi berprestasi yaitu Moderate task difficulty/memilih tugas dengan tingkat kesulitan sedang, Persistence/ Ketahanan atau Ketekunan, Feedback/ Umpan Balik, Responsibility/ Bertanggung Jawab, innovativeness/ inovasi. Metode yang dapat digunakan visualisasi, ilustrasi. ${ }^{21,24,31-32}$

Elemen selanjutnya yaitu Self Study, dalam pencapaian pelatihan motivasi, peserta diberi panduan tentang bagaimana berfikir, berbicara dan bertindak sebagai orang yang mempunyai prestasi tinggi kemudian mengenali tujuan hidup mereka dalam waktu dekat dengan metode interaksi, simulasi, melalui materi self study ini peserta diberi banyak kesempatan untuk mempelajari diri mereka masing-masing. Peserta harus mengetahui apa yang dibutuhkan oleh diri mereka, apa yang dimiliki, bagaimana keadaan lingkungan sekitar atau dengan kata lain peserta harus menemukan potret diri mereka dengan mengkaji kelemahan dan kekuatan yang ada pada diri mereka, apa tujuan hidupnya, norma-norma hidup dalam lingkungan. Materi ini telah tercakup dalam beberapa ciri motivasi berprestasi yaitu menerima dan menggunakan umpan balik (feedback) dan memperhitungkan resiko. Maksudnya adalah dalam training ini peserta berkesempatan untuk lebih tau kelemahan dan kekuatannya juga hal lain tentang dirinya baik dari proses lain. Umpan balik tersebut sangan berguna bagi peserta dalam merencanakan langkah-langkah selanjutnya yang diperlukan dalam rangka pencapaian tujuan dan dalam estimasi kesuksesan atau kegagalan yang akan dicapai(memperhitungkan resiko). ${ }^{21,24,31-32}$

Planning and goal setting adalah konsep penetapan tujuan yang akan dikenalkan dengan maksud agar peserta merasa berapa pentingnya penetapan tujuan dalam kehidupan sehari-hari. Untuk lebih mengetahui dan memahami konsep penetapan tujuan, seseorang harus mengenal terlebih dahulu dirinya, apa yang menjadi kebutuhannya dan mengenal bagaimana lingkungan. Berdasarkan ini semua, kemudian disusun dan dirumuskan tujuan yang akan ditetapkan dengan berdasarkan anggapan bahwa tujuan itu harus berarti bagi diri pribadi (sesuai kebutuhan), harus realistis (sesuai dengan kemampuan yang dimiliki), megandung resiko sedang, ada batas waktu, dapat diukur (sesuai kondisi lingkungan), materi goal setting ini telah mencakup ciri orientasi pada prestasi dan mempunyai perasaan yang kuat untuk mecapai tujuan dan hasil yang sebaik-baiknya. Metode yang digunakan memakai metode simulasi dan kontemplasi. ${ }^{21,24,31-32}$

Sesi interpersonal support peserta dianggap sebagai subjek yang dinamis dapat mempengaruhi dan lingkungan membantu satu sama lain. Kontak yang terjadi antara peserta dan pelatih sangat menentukan pematangan proses belajar. Sesi ini secara otomatis akan tercakup dalam keseluruhan aspek manakala melakukan relasi interpersonal, baik dengan peserta lain maupun dengan fasilitator. Dalam sesi ini disusun metode-metode belajar sedimikian rupa sehingga peserta akan selalu berkesempatan untuk berdinamika secara aktif dalam kelompok dengan didampingi fasilitator. ${ }^{21,24,31-32}$ Pada sesi ini suasana saling memotivasi karena adanya interaksi dan kompetisi antara anggota pelatihan.

Berdasarkan tabel 4.1, motivasi berprestasi mahasiswa yang telah dikategorikan menjadi 3 kategori, pada peningkatan rata-rata kelompok intervensi maupun kelompok kontrol tidak ada peningkatan yang bermakna, rata-rata kelompok sebelum perlakuan mempunyai kategori cukup dan setelah perlakuan mempunyai kategori cukup. Tetapi apabila dilihat peningkatan secara deskriptif pada kelompok kontrrol 2 mahasiswa yang mengalami peningkatan motivasi berprestasi menjadi kategori tinggi dan pada kelompok intervensi 6 mahasiswa yang mengalami peningkatan motivasi berprestasi menjadi kategori tinggi.

Pada analisis tes tanda memberikan kesimpulan yang berbeda. Hasil analisis menunjukkan, pada kelompok intervensi terdapat 20 mahasiswa yang mengalami peningkatan motivasi berprestasi dan pada kelompok kontrol hanya 13 mahasiswa yang mengalami peningkatan motivasi berprestasi. Kemudian peneliti melakukan uji anacova dimana pre-test dijadikan sebagai kovariat, hasil analisi menunjukkan terdapat perbedaan yang bermakna $(\mathrm{p}<0.05)$. Artinya, motivasi berprestasi secara signifikan dipengaruhi oleh perbedaan perlakuan dengan melakukan kontrol terhadap responden 
dengan menggunakan hasil pre-test atau sebelum diberikan perlakuan.

Hasil Uji tanda selaras dengan analisis peningkatan rerata pada kelompok kontrol dan perlakuan. Hasil menunjukkan terdapat penurunan rerata motivasi berprestasi pada kelompok kontrol (-2,39 \%) dan pada kelompok perlakuan terdapat peningkatan rerata sebesar (6,93 \%) setelah diberikan perlakuan.

Walaupun setelah dikategorikan motivasi berprestasi mahasiswa tidak mengalami peningkatan tetapi secara statistik motivasi berprestasi mempunyai nilai yang bermakna setelah dilakukan beberapa analisis. Hal ini terjadi karena pada pengkategorian nilai tidak asli ada beberapa nilai yang hilang.

Post-test dalam penelitian ini dilakukan setelah 2 bulan diberikan perlakuan, hasil post-tes tersebut $6,93 \%$ peningkatan rerata. Hal ini menunjukkan meningkatan motivasi berprestasi hanya sedikit. Jika post-tes dilakukan pada bulan ke tiga kemungkinan akan terjadi peningkatan kembali dan maksimal peningkatan pada bulan ke 6. Hal ini sesuai dengan hasilpenelitian Elias, Lovez, Chair dana Havenar. Berdasarkan beberapa penelitian tersebut setelah diberikan training motivasi dan diamati setiap minggu maka terjadi peningkatan, adapun peningkatan tersebut dapat terlihat pada 6 minggu setelah dilakukan perlakuan, pada bulam ke 3 mengalami kenaikan motivasi yang pesat dan puncak peningkatan motivasi terjadi pada bulan ke 6 kemudian pada penilaian bulan ke 9 terjadi penurunan dari nilai maksimal dan pada bulan ke 12 semakin penurunan tetapi nilai tersebut masih diatas nilai awal (baseline). Perubahan motivasi tersebut didukung oleh berbagai teori, motivasi mempuyai sifat berubah-ubah dan dipengaruhi oleh beberapa faktor intrinsik maupun ekstrinsik. ${ }^{16,21-23}$

Evaluasi pelatihan dalam penelitian ini menggunakan pendekatan 4 level evaluasi pelatihan menurut Donald L Kirkpatrick dan dilakukan secara sederhana, 4 level tersebut yaitu; level 1 adalah evaluasi reaksi, level 2 adalah evaluasi belajar, level 3 adalah evaluasi perilaku dan level 4 adalah evaluasi hasil, tetapi yang dilakukan dalam penelitian hanya 3 level.

Adapun hasil evaluasi tersebut adalah : Evaluasi reaksi digunakan untuk mengukur kepuasan peserta mengikuti pelatihan pembelajaran, mencakup sejauh manapenerimaan materi dan kesan pelatihan melalui lembar kesan dan pesan. Berdasarkan evaluasi setelah diadakannya pelatihan ini semua peserta memberikan kesan senang dan merasa pelatihan seperti ini bermanfaat karena peserta dapat memperoleh ilmu, pengalaman baru, wawasan baru dan membangkitkan semangat untuk belajar lebih giat lagi tetapi sebagian peserta memberi masukan waktu pelaksanaan sebaiknya diberikan tidak saat akan melakukan praktik dilapangan.

Selanjutnya Evaluasi belajar dan perilaku diperoleh dari wawancara yang dilakukan setelah pelatihan. Wawancara dilakukan pada dua orang mahasiswa yaitu mahasiswa yang diberikan pelatihan motivasi dan yang tidak diberikan pelatihan motivasi. Adapun hasil wawancara tersebut mahasiswa memahami tujuan kuliah, urgensi tekun, dan merasa ada semangat baru. Sedangkan hasil wawancara terhadap mahasiswa yang tidak diberikan pelatihan motivasi, merasa tidak ada perubahan apapun selama 2 bulan kebelakang.

Evaluasi prilaku yang dilakukan 5 bulan setelah diberikan perlakuan, peneliti melakukan wawancara terhadap beberapa dosen dan melihat data dibagian evaluasi terhadap perilaku mahasiswa yang terdapat pada kelompok kontrol dan perlakuan, adapun hasil evaluasi dari kelompok perlakuan terlihat beberapa kemajuan diantaranya lebih aktif bertanya, tidak ada laporan mahasiswa yang terlambat masuk kelas dan tidak hadir pada saat perkuliahan. Hasil Evaluasi dari kelompok kontrol dilaporkan terdapat 4 mahasiswa yang pernah 3-6 kali datang terlambat dan 1 mahasiswa dilaporkan tidak melanjutkan kuliah karena jarang hadir pada saat perkuliahan.

Bagaimanapun juga motivasi berprestasi seseorang dipengaruhi oleh banyak hal yaitu faktor internal (kemampuan, minat, konsep diri) dan faktor eksternal (pengakuan prestasi, pola asuh, dorongan orang tua, dorongan teman). Sebagaimana beberapa hasil penelitian menunjukkan motivasi berprestasi dipengaruhi oleh beberapa faktor.

penelitian Acharya dan Joshi meneliti pengaruh dorongan orang tua terhadap motivasi berprestasi, hasil menunjukkan ada hubungan yang signifikan antara dorongan orang tua dengan motivasi berprestasi. ${ }^{33}$

Menurut penelitian Roy, meneliti hubungan antara kecerdasan emosional dan motivasi berprestasi dari 105 sampel, dengan jenis kelamin laki-laki 48 sampel dan perempuan 57, hasil dari penelitian tersebut motivasi berprestasi berkorelasi positif terhadap kecerdasan emosinal anak perempuan. $^{34}$

Menurut hasil penelitian Hartaji terdapat beberapa gambaran mengenai motivasi berprestasi mahasiswa atas dasar pilihan orang tua, subjek tersebut memiliki pribadi kurang tanggung jawab terhadap kuliah, tidak ada pertimbangan resiko, penyelesaian tugas yang tidak efektif, tidak kreatif 
dan inovatif, dan tidak memanfaatkan waktu untuk belajar. ${ }^{35}$

Berdasarkan beberapa penelitian Ada perbedaan yang signifikan motivasi berprestasi siswa dengan konsep diri negatif dan konsep diri positif sebesar 4,91\%. Hal tersebut ditunjukkan dari hasil Uji-t dengan nilai $\mathrm{t}$ hitung $=37,653$ lebih besar dari $\mathrm{t}$ tabel $=1.9778$ pada taraf signifikasi $5 \%$, df $=134$ dan dari skor rata-rata motivasi berprestasi siswa pada kelas dengan konsep diri positif sebesar 83,65 sedangkan pada kelas dengan konsep diri negatif sebesar 78,74. ${ }^{36-}$ 37

Pada penelitian Widowati mengenai pengaruh pola asuh terhadap motivasi belajar bahwa ada hubungan antara pola asuh orang tua dengan prestasi belajar sosiologi siswa kelas XI SMA Negeri 1 Sidoharjo Wonogiri, yang berarti pola asuh yang diterapkan oleh orang tua mempunyai peranan yang penting dalam keberhasilan belajar anak, pola asuh orang tua berkaitan derat dengan cara orang tua mendidik anak, apakah ia ikut mendorong, merangsang dan membimbing terhadap aktivitas anaknya atau tidak. $3^{8}$

Peran orangtua merupakan komponen penting dalam pendidikan anak. Hal ini menuntut adanya kontak secara langsung yang dapat diwujudkan dalam bentuk dukungan orangtua pada anaknya. Berdasarkan penelitian Acharya yang meneliti hubungan dukungan orang tua terhadap motivasi berprestasi dari 500 remaja di India, hasil menunjukkan terdapat hubungan yang signifikan antara motivas berprestasi dengan dukungan orang tua. ${ }^{33}$

Hasil penelitian Hikmah yang meneliti hubungan antara dukungan sosial teman sebaya dengan motivasi berprestasi, hasil menunjukkan terdapat hubungan positif antara hubungan sosial teman sebaya dengan motivasi berprestasi, semakin tinggi dukungan sosial teman sebaya maka akan semakin tinggi motivasi berprestasi belajar siswa. $^{39}$

Berdasarkan beberapa penelitian tersebut untuk meningkatkan motivasi berprestasi tidak cukup dilakukan melalui satu macam cara tetapi langkah strategi dalam meningkatkan motivasi berprestasi adalah mengupayakan perbaikan dari semua aspek baik itu motivasi yang bersifat internal maupun eksternal yang dapat mempengaruhi motivasi berprestasi mahasiswa.

\section{Kesimpulan}

Program Achievement Motivation Training (pelatihan Motivasi Berprestasi) ini berpengaruh positif terhadap peningkatan motivasi berprestasi. Mahasiswa yang diberikan program AMT mengalami peningkatan motivasi berprestasi sebesar 6,97\% dan mahasiswa yang tidak diberikan program AMT mengalami penurunan motivasi berprestasi sebesar 2,39\%, walaupun pemberian AMT diberikan hanya satu kali.

\section{Daftar Pustaka}

1. HPEQ-DIKTI. Naskah Akademik Sistem Pendidikan Bidan di Indonesia. Jakarta; 2012.

2. HPEQ-DIKTI. Praktik Baik Uji Kompetensi Tenaga Kesehatan. HPEQ-DIKTI. Editor. Jakarta: HPEQ-DIKTI; 2012.

3. Tren Ketenagakerjaan Sosial di Indonesia. I.L.O. (ILO). Editor. Jakarta: Kantor ILO untuk Indonesia; 2013.

4. Sukmadinata NS. Landasan Psikologi Proses. Bandung: PT.Remaja Rosdakarya; 2012.

5. Rumiani. Prokrastinasi ditinjau dari Motivasi Berprestasi dan Stres Mahasiswa. Psikologi. Semarang: Universitas Diponegoro; 2006.

6. Reeve J. Understanding Motivation and Emotion. United States of America: WILEY; 2009.

7. Djiwandono SEW. Psikologi Pendidikan. Jakarta: PT.Grasindo; 2004.

8. McClelland DC, et al. The Achievement Motive. New York: Appleton-Century-Crolts, Inc; 1987.

9. Sudarmanto. Kinerja dan Pengembangan Kompetensi SDM, ed. Adinugraha. Jogjakarta: Pustaka Pelajar; 2009.

10. Wibowo. Manajemen Kinerja. Jakarta: Rajawali pers; 2013.

11. Kusurkar RA, et al. How motivation affects academic performance: a structural equation modelling analysis. Adv Health Sci Educ Theory Pract, 2013. 18(1): p. 57-69.

12. Sugianto. Kontribusi Gaya Belajar dan Motivasi Berprestasi terhadap Prestasi Akademik Siswa Kelas XI SMA Negeri 10. Semarang: Universitas Negeri Jogjakarta; 2008.

13. Smith RL. Achievement Motivation Training: An Evidence-Based Approach to Enhancing Performance. VISTAS Online; 2011.

14. Richard E, Boyatzis, David C. McClelland: Biographical Statement and Synopsis of His Work; 2000.

15. Garliah L, dkk. Peran Pola Asuh Orang Tua dalam Motivasi Berprestasi. Psikologia, 2005. Volume I No. 1 p. 30-39.

16. Elias H. Achievement Motivation Training for University Students: Effects on Afective and Cognitive Achievement Motivation. Universitas Pertanian Malaysia; 1994.

17. Budiarto E. Metodologi Penelitian Kedokteran. Jakarta: EGC; 2004.

18. Azwar S. Reliabilitas dan Validitas. IV ed. Yogyakarta: Pustaka Pelajar: 2012.

19. Havenar J. Adapted motivational interviewing for increasing physical activity: A 12 month clinical trial. 2007, Arizona State University: Ann Arbor. p. $132-n / a$ 
20. Havenar J. Adapted motivational interviewing for increasing physical activity: A 12 month clinical trial. 2007, Arizona State University: Ann Arbor. p. 132-n/a

21. Lopez BJ. The efficacy of an achievement motivation program. 2008, Texas A\&M University - Corpus Christi: Ann Arbor. p. 151-n/a.

22. Chair SY, et al. Long-term effect of motivational interviewing on clinical and psychological outcomes and health-related quality of life in cardiac rehabilitation patients with poor motivation in Hong Kong: a randomized controlled trial. Clinical Rehabilitation, 2013. 27(12): p. 1107-17.

23. Sistem Pendidikan Bidan di Indonesia, AIPKIND, Editor. Jakarta: IBI dan AIPKIND; 2012.

24. Kolodziej S. The Role of achievement Motivation in educational Aspiration and Performance; 2010.

25. Gibson, Ivancevich, and Donnelly. Organisasi: Perilaku, Struktur, Proses. Binarupa Aksara; 2012.

26. Mangkunegara AP, ed. Evaluasi Kinerja SDM. Bandung: PT.Refika Aditama; 2012.

27. Amrai K, et al. The relationship between academic motivation and academic achievement students. Procedia - Social and Behavioral Sciences, 2011. 15(0): p. 399-402.

28. Faturachman. Pengaruh Motivasi Berprestasi terhadap Kesiapan Belajar, Pelaksanaan Prakerin dan Pencapaian Kompetensi Mata Pelajaran Produktif Teknik Kendaraan Ringan Kelas XI. Julnal UPI; 2011.

29. McClelland DC. Human Motivation. Cambridge: Cambridge Univercity Press; 1987.

30. Varga K. Who Gains from Achievement Motivation Training? Vikalpa, 1977. 2: p. 187-200.
31. Uno HB. Teori Motivasi dan Pengukurannya. Jakarta: Bumi Aksara; 2012.

32. Indrawati. Konsep Dasar Evaluasi Diklat. BPPK.DepKeu; 2012.

33. Delarosa A. Motivasi Berprestasi ditinjau dari Kompetisi dengan Teman sebaya. Universitas Katolik Soegijapranata Semarang; 2009.

34. Roy B, Sinha R, and Suman S, Emotional Intelligence And Academic Achievement Motivation Among Adolescents: A Relationship Study. Researchers World, 2013. 4(2): p. 126-130.

35. Hartaji RDA. Motivasi Berprestasi Siswa yang Berkuliah dengan Jurusan Pilihan Orang Tua. Jakarta: Universitas Guna Dharma; 2009.

36. Prasetyo J. Pengaruh Konsep Diri dan Lingkungan Keluarga Terhadap Motivasi Berprestasi Siswa Program Studi Teknik Kendaraan Ringan di SMK Muhammadiyah Gamping. Universitas Negeri Jogjakarta; 2012.

37. Liu HJ. The Relation of Academic Self-Concept to Motivation among University EFL Students. Feng Chia Journal of Humanities and Social Sciences, 2010. No. 20,: p. 207-25.

38. Shui-fong $\mathrm{L}$, et al. The effects of competition on achievement motivation in Chinese classrooms. British Journal of Educational Psychology, 2004. 74: p. 281-296.

39. Widowati SND. Hubungan antara pola asuh orang tua, motivasi belajar, Kedewasaan dan kedisiplinan siswa dengan prestasi Belajar sosiologi siswa kelas XI SMA negeri IV Sidoharjo wonogiri, in Fakultas Keguruan dan Ilmu Pendidikan. SURAKARTA: Uiversitas Sebelas Maret Surakarta; 2013. 